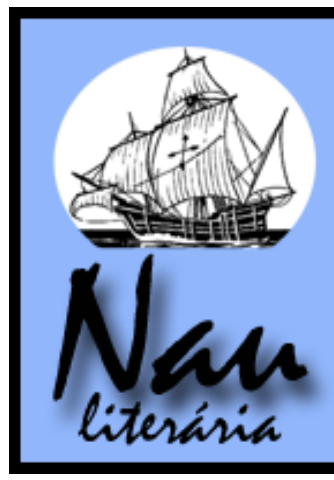

Nau Literária: crítica e teoria de literaturas • seer.ufrgs.br/NauLiteraria

ISSN 1981-4526 • PPG-LET-UFRGS • Porto Alegre • Vol. 10 N. 2 • jul/dez 2014

Dossiê: Migração, exílio e identidade

\title{
Representações de exílio e nacionalismo em Gonçalves Dias
}

\section{Renata Ribeiro Lima*}

Resumo: Este ensaio propõe uma breve passagem pela biografia e pela obra do poeta Gonçalves Dias, com ênfase nos poemas e nos trechos de sua correspondência em que trata do exílio, analisando-os à luz dos estudos pós-coloniais. Investiga-se a maneira como os sucessivos exílios a que foi submetido o poeta afetaram a sua forma de perceber e de atribuir valores aos lugares. Verifica-se como, nas representações do nacional em Gonçalves Dias, construídas a partir do duplo olhar do exilado, se materializam conflitos de identidade, cruzando-se olhares do colonizado e do colonizador num amálgama de que era testemunha viva a própria pessoa do poeta.

Palavras-chave: Exílio; Identidade; Representação; Nacionalismo; Gonçalves Dias.

\begin{abstract}
This essay proposes a brief reading of the poet Gonçalves Dias' biography and work, focusing on the poems and parts of his letters in which he talks about the exile, in the light of Cultural Studies. It inquires how the successive exiles the poet came through affected his way of perceiving and attributing value to places. It verifies how, in the representations of the national in Gonçalves Dias' writing, built from the double perspective of the exile, identity conflicts are materialized, crossing the colonized and the colonizer views in a mix of which he was a witness himself.
\end{abstract}

Keywords: Exile; Identity; Representation;

Nationalism; Gonçalves Dias.

\section{Patrie! doux nom que l'exil fait comprendre!}

(Marino Faliero, citado por Gonçalves Dias)

Pode parecer um tanto óbvio, passados tantos séculos do Romantismo brasileiro e das suas releituras, como no Modernismo, falar de representações do exílio e do nacionalismo num autor como Gonçalves Dias, conhecido justamente por sua "Canção do Exílio" e por seu papel na promoção do elemento nativo - indígena - a símbolo nacional. Entretanto, o novo olhar que tem sido lançado sobre as questões de cultura e identidade diante da dinâmica de mobilidade dos últimos séculos faz com que se renove o interesse sobre os momentos decisivos da construção identitária brasileira. A quebra de fronteiras desencadeada pelo processo de globalização nos faz refletir cada vez mais sobre o que é ser brasileiro, latinoamericano ou europeu - isto é, sobre as identidades culturais.

Os estudos a este respeito têm se centrado principalmente no século $\mathrm{XX}$, pelos vários eventos de migrações e exílios que nesse tempo tiveram lugar, em decorrência dos conflitos mundiais e do desenvolvimento dos meios de transporte e de comunicação. No entanto, vale

\footnotetext{
* Mestranda em Estudos Literários, Culturais e Interartes na Faculdade de Letras da Universidade do Porto. Licenciada em Letras pela Universidade Federal do Maranhão.
} 
ressaltar que, embora em menor escala, nos séculos anteriores também ocorriam diversas situações de deslocamento que punham em jogo as identidades, especialmente no século XVI - na chamada "Era dos Descobrimentos" - e a partir do século XIX, quando os transportes conheceram um grande desenvolvimento tecnológico. Além do mais, é no século XIX que se desenvolvem teorias que procuram identificar as características de um povo através de aspectos físicos e comportamentais, o que afetou decisivamente as representações que se faziam do Eu e do Outro, do nacional e do estrangeiro, do "primitivo" e do "civilizado", para usar os termos da época.

É nesse contexto que Gonçalves Dias, no curto espaço de sua existência - 41 anos, de 10 de agosto de 1823 a 3 de novembro de 1864 - percorreu vários espaços, em viagens nada curtas. Boa parte de sua vida foi passada dentro de navios a vela ou a vapor. As viagens do Maranhão para a Europa ou para o Rio de Janeiro levavam quase o mesmo tempo: cerca de um mês. Nesses "não-lugares" oceânicos, bem como nos lugares de partida e de chegada, o poeta teve ocasião de criar e recriar, de uma perspectiva fronteiriça, diversas representações da sua própria identidade e da identidade nacional, em meio a um movimento cultural que o incentivava a mesclar essas duas identidades - o Romantismo. Falar de si era falar de sua nação.

Neste ensaio, o que se propõe é uma breve passagem por sua biografia e por seus textos - que se misturam tantas vezes, de propósito ou por "ironia do destino" -, com ênfase nos poemas e nos trechos da sua correspondência em que trata do exílio, analisando-os à luz dos estudos pós-coloniais. Com o auxílio das reflexões de autores como Stuart Hall, Edward Said e outros mais centrados na cultura brasileira, como Renato Ortiz e Antonio Candido, pretende-se investigar a maneira como os sucessivos exílios a que foi submetido o poeta afetaram a sua forma de perceber e de atribuir valores aos lugares.

1 Relações Brasil-Portugal: mestiçagem e conflito de identidades

As condições em que nasceu Gonçalves Dias tiveram, possivelmente, um papel acentuado em sua construção identitária individual e coletiva: filho de um português com uma mestiça (não se sabe ao certo se cafuza ${ }^{1}$ ou mameluca ${ }^{2}$ ), um ano após o Grito de “Independência ou Morte!” de Dom Pedro I às margens do Ipiranga. Nessa altura, a Vila de Caxias era habitada predominantemente por uma população lusitana, que constituía a classe

\footnotetext{
${ }^{1}$ Mestiça de negro e índio.

${ }^{2}$ Mestiça de branco e índio.
} 
dominante no comércio, na agricultura, na pecuária, na Igreja e na educação. O intenso tráfego marítimo com a metrópole, justificado pela maior proximidade geográfica com a Europa, tornava mais fáceis as trocas comerciais e culturais com Portugal do que com o sudeste e com o sul do país. Os filhos dos comerciantes ricos estudavam em Portugal, como Gonçalves Dias e seus condiscípulos João Duarte Lisboa Serra e Alexandre Teófilo de Carvalho Leal. Sendo assim, não havia interesse no rompimento com a metrópole, o que deu origem a diversos conflitos até a adesão (forçada) à independência, em 28 de julho de 1823. A cidade de Caxias só adere em 1. ${ }^{\circ}$ de agosto do mesmo ano, nove dias antes de o poeta nascer. Por essa razão é que o menino Gonçalves Dias vem à luz não precisamente em Caxias, mas afastado cerca de dez léguas, no sítio Boa Vista, em Jatobá, para fugir à hostilidade contra os portugueses que começava a se instalar e a ameaçar o seu pai, Manuel Gonçalves Dias.

Assim, para além da situação de separação física da pátria que enfrentará mais tarde - que, por si só é uma potencial geradora de nacionalismo (cf. SAID, 2003) -, há no percurso gonçalvino uma mistura pessoal entre representações do colonizado e do colonizador. Essa ambivalência faz com que o poeta exalte tanto o índio quanto o Imperador de nacionalidade portuguesa, colocando-se ao lado tanto da "raça marginal" quanto das elites - pois num dado momento, interessava às elites a "civilização" dessa "raça" e a sua integração ao projeto de nação.

A relação Brasil-Portugal para Gonçalves Dias enquanto pessoa era certamente muito complexa. Quando, ainda adolescente, emigra para Coimbra, entra em contato com o romantismo europeu e com suas tentativas de estabelecer as culturas nacionais por meio da busca de modelos pitorescos do passado. A Europa tinha vivido a sua Idade Média, mas e o Brasil? Sabendo que uma cultura nacional necessita de mitos para sobreviver, e que os mitos requerem narrativas de gênese (cf. HALL, 2006), Gonçalves Dias e os demais intelectuais brasileiros da época não tinham alternativa a não ser procurar essa origem no elemento nativo - o índio. Era essa "origem misteriosa" do povo brasileiro que o Império tinha interesse em reconstituir, ou melhor, em reconstruir - interesse este manifesto pelas ações do Instituto Histórico e Geográfico do Brasil para reunir documentos e estudos sobre os índios. Era a narrativa da nação brasileira que nascia e elegia seus elementos simbólicos.

Estando-se a par disso, não surpreende que a primeira poesia impressa de Gonçalves Dias, em Coimbra, seja de apoio à aclamação do imperador Dom Pedro II, em 3 de maio de 1841 (cf. LIMA, 1942). Na ocasião, houve, inclusive, uma festa, cujo relato encontrado por LIMA (1942, p. 5) é um bom exemplo das relações de então entre os países: 
entrelaçadas tremulavão o auriverde pavilhão da Independencia, e o das Quinas Portuguezas; enlace este que se harmonisava perfeitamente com o fraternal abraço, em que hião ahi estreitados os Mancebos das duas nações; que muitos dos nossos amigos do Continente, Provincias e Possessões ultramarinas - irmãos nossos pelo amor, como o são por crença, linguagem e costumes, mas (o que mais tocante é) participárão dos sentimentos, que nos dominavão. (...)

A Bandeira Brazileira foi então arvorada sobre o edificio, em frente do qual esteve todo o dia postada uma numerosa Guarda do Corpo de Municipaes da cidade.

O Banquete foi esplendido, a musica acompanhava os brindes patrioticos, e o prazer recrescia incessantemente.

Foi então; - foi no meio do enthusiasmo, que lavrava em todos os corações, que foram recitadas as Poesias, que se seguem (...).

Gonçalves Dias também falará, em carta a um poeta português que migrou para o Brasil, em termos semelhantes: "nenhuma outra gente que mais ames depois da tua do que esta, que tendo a mesma origem e falando a mesma língua, (...) abrem hospitaleiramente os braços (...)" (1849 in DIAS, 1998, p. 1069). No entanto, de modo algum se pode afirmar que o poeta maranhense fosse entusiasta de uma eterna colonização cultural portuguesa sobre o Brasil; como também deixou expresso em várias cartas, Dias acreditava que a interferência do tupi e das línguas africanas sobre o português brasileiro era enriquecedora, além de geradora de diferenças irrecuperáveis entre os usos da língua nos dois países (cf. DIAS, 1998, p. 1070, 1132-1133). Gonçalves Dias foi, antes de tudo, um homem do seu tempo - um período de transição, de descolonização literária, em que as fronteiras culturais eram pouco nítidas.

Retornando-se à ordem cronológica dos fatos, volte-se à estada do poeta em Coimbra, enquanto estudante de Direito. Foi um tempo de grandes dificuldades econômicas, pois seu pai havia falecido antes mesmo da sua viagem e era a madrasta quem lhe enviava auxílio. $\mathrm{Na}$ época da Balaiada, essa ajuda foi cortada; razão pela qual o poeta só pôde permanecer na Universidade devido ao socorro dos amigos (ao menos até que a situação melhorasse). Por esse motivo, há nas cartas do poeta dois tipos de representações desse período: uma negativa e outra positiva. A primeira, quando ainda estava vivenciado a experiência ruim com o lugar; e a segunda, quando já haviam passado alguns anos dessa vivência. Como diz Manuel Bandeira, "É que só lhe sorria à imaginação o que lhe ficava longe, no tempo ou no espaço." (1998, p. 18).

A relação do poeta com Portugal é ambivalente: ora se refere ao país como "terra de meus Pais" (DIAS, 1998, p. 1036), ora como "terra maldita e aporrinhada" (Idem, Ibidem, p. 1038), dependendo das circunstâncias. Assim, o mesmo Dias afirma, logo após voltar de Portugal, em 1845: "Triste foi a minha vida de Coimbra - que é triste viver fora da pátria, subir degraus alheios - e por esmola sentar-se à mesa estranha. (...) Mas ser desconhecido ou mal conhecido, mas sentir dores d'alma, mas viver e morrer sem nome (...) - é mais triste 
ainda.” (DIAS, 1998, p. 1041). Quatro anos depois, refere-se ao mesmo período de sua vida nos seguintes termos: “Os mais alegres anos de minha juventude correram-me em Portugal, lá me ficaram amigos que me pesa de ter deixado talvez para sempre; e não sem saudades me posso agora recordar dos sítios que vi, das pessoas que amei e da terra que me foi como uma segunda pátria." (DIAS, 1998, p. 1068).

Talvez o destinatário das cartas - no primeiro exemplo o amigo maranhense Teófilo Leal; no segundo, o poeta português João d'Alboim - tenha tido alguma influência na maneira como Dias se referia aos anos em Coimbra, mas também é provável que o tempo tenha se encarregado de lhe revelar novos aspectos daquela experiência. Como ele previa, mais triste teria sido que ele não tivesse estudado em Coimbra, sem o que talvez não tivesse a erudição e o distanciamento necessários para a missão a que se veio a propor: ser "o Primeiro Poeta do Brasil”" (cf. PEREIRA, 1943, p. 85).

Se a sua visão de Portugal era variável, a da terra natal também não era fixa: em 1843, compõe a Canção do Exílio, em Coimbra; mas quando volta a Caxias, sente-se deslocado: "Meu amigo - Aqui estou como Gulliver quando acordou na terra dos Pigmeus; - uma infinidade de fios sutilíssimos me prendem - e eu não os vejo - sinto somente.” (DIAS, 1998, p. 1042). O texto da Canção do Exílio nos dá pistas para compreender essa aparente volubilidade do poeta:

Minha terra tem palmeiras, Onde canta o Sabiá;

As aves, que aqui gorjeiam, Não gorjeiam como lá.

Nosso céu tem mais estrelas, Nossas várzeas têm mais flores, Nossos bosques têm mais vida, Nossa vida mais amores.

Em cismar, sozinho, à noite, Mais prazer encontro eu lá; Minha terra tem palmeiras, Onde canta o Sabiá.
Minha terra tem primores, Que tais não encontro eu cá; Em cismar - sozinho, à noite Mais prazer encontro eu lá; Minha terra tem palmeiras, Onde canta o Sabiá.

Não permita Deus que eu morra, Sem que eu volte para lá; Sem que desfrute os primores Que não encontro por cá; Sem qu'inda aviste as palmeiras, Onde canta o Sabiá. (DIAS, 1998, p. 106-107)

Nesta canção, pelas constantes repetições dos advérbios "cá" e "lá", assim como pelas comparações estabelecidas entre as duas terras, verificamos aquilo que Edward Said nomeou de "consciência contrapontística" (2003, p. 59). Explica o estudioso palestino que

Para os exilados, os hábitos de vida, expressão ou atividade no novo ambiente ocorrem inevitavelmente contra o pano de fundo da memória dessas coisas em outro ambiente. Assim, ambos os ambientes são vívidos, reais, ocorrem juntos como no contraponto. (Idem, Ibidem). 
Essa consciência de dois lugares ao mesmo tempo possivelmente fazia com que o poeta nunca se sentisse totalmente em casa. No período de pós-exílio, escreveu também um texto em prosa chamado Meditação, que não chegou a ser publicado na íntegra pelas ideias abolicionistas que trazia e que poderiam comprometer o autor na sua dependência da administração pública (cf. GRIZOSTE, 2013). Nos fragmentos desse texto presentes na compilação atual de sua obra completa (DIAS, 1998), o autor vê a própria terra com os olhos de alguém que vem de fora. No trecho que se segue,

Por isto o estrangeiro que chega a algum ponto do vasto império - consulta de novo a sua
derrota e observa atentamente os astros - porque julga que um vento inimigo o levou às costas
d'África.
E conhece por fim que está no Brasil - na terra da liberdade, na terra ataviada de primores e
esclarecida por um céu estrelado e magnífico! Mas grande parte de sua população é escrava -
mas a sua riqueza consiste nos escravos - mas o sorriso - o deleite do seu comerciante - do seu
agrícola - e o alimento de todos os seus habitantes é comprado à custa do sangue do escravo!
E nos lábios do estrangeiro, que aporta ao Brasil, desponta um sorriso irônico e despeitoso -e
ele diz, consigo, que a terra - da escravidão - não pode durar muito: porque ele é crente, e sabe
que os homens são feitos do mesmo barro - sujeitos às mesmas dores e às mesmas
necessidades. (DIAS, 1998, p. 727)

Daqui também se conclui quão injustas foram algumas críticas feitas ao poeta, quanto à omissão do elemento negro na composição da narrativa nacional. Vale lembrar que o motivo do exílio figurou, em sua obra poética, também do ponto de vista do negro que vinha forçado para o Brasil: como exemplo, recorde-se o poema "A Escrava” (DIAS, 1998, p. 171173), cuja epígrafe foi utilizada neste artigo, em que o eu-lírico é uma negra que rememora, saudosa, o "Doce país de Congo" e as suas paisagens, desejando morrer onde nascera, assim como o eu-lírico de "Canção do Exílio". É preciso lembrar, a este respeito, que não havia ainda liberdade de imprensa no Brasil daquela época, e que, como bem aponta GRIZOSTE (2013, p. 377), "louvar o negro numa sociedade escravocrata em que ele era a principal vítima seria uma heresia".

Este novo olhar que Dias dirigiu à sua terra e aos seus atores sociais constituiu uma experiência negativa em relação à sua terra. Os mesmos ambientes iam tendo representações distintas em função desses olhares, constantemente renovados. A experiência, como formula o geógrafo humanista Yi-Fu Tuan (1983, p. 10) "implica a capacidade de aprender a partir da própria vivência. (...) $\mathrm{O}$ dado não pode ser conhecido em sua essência. O que pode ser conhecido é uma realidade que é um constructo da experiência, uma criação de sentimento e pensamento". Assim, o que Dias expressava não era determinado lugar tal como era (o que seria impossível), mas sim tal como se lhe apresentava à experiência e à memória - e quanto mais distante no tempo e no espaço, mais idealizado. Isto também por que, segundo afirma 
Edward Said (2003, p. 49), “a interação entre nacionalismo e exílio é como a dialética hegeliana do senhor e do escravo, opostos que informam e constituem um ao outro. Em seus primeiros estágios, todos os nacionalismos se desenvolvem a partir de uma situação de separação." Said fala também nos "pais fundadores" desses nacionalismos, com seus "textos básicos, quase religiosos, uma retórica do pertencer" (Ibidem). Foi por meio da experiência do exílio que Gonçalves Dias se tornou um dos pais fundadores da identidade brasileira, e seus versos e símbolos permeiam vários outros textos fundamentais da cultura do país, como o Hino Nacional e as várias paródias da Canção do Exílio (cf. CINTRÃO, 1988 e MESQUITA, 2001

Vale lembrar, contudo, que à experiência do exílio também se somou o empenho em construir uma cultura válida no país, que vinha tomando forma desde o Arcadismo e que coincidiu historicamente com os eventos que levaram à independência (CANDIDO, 2010). No primeiro quartel do século XIX se esboçam as condições para definir os papéis sociais do escritor e do público no Brasil, gerando uma busca voluntária, por partes dos escritores, de exprimir a sensibilidade nacional, utilizando o nativismo e o civismo como justificação (Idem, Ibidem).

2 Relações Maranhão-Rio de Janeiro-Europa: o exílio na cidade-corte

Gonçalves Dias pretendia exercer a advocacia em Caxias, por falta de melhor opção, quando surge o convite do amigo Alexandre Teófilo para que fosse viver com ele, em São Luís. Foi também o amigo quem intercedeu por G. Dias junto ao presidente da província e pediu para o poeta uma passagem de Estado, no que fora prontamente atendido (cf. BANDEIRA, 1998). Assim se iniciava uma nova migração na vida do poeta, pois ir para a cidade-corte representava encontrar um meio propício para o seu desenvolvimento intelectual e profissional.

Foi lá, em 1847, que Gonçalves Dias publicou os seus Primeiros Cantos e que começou a estabelecer uma rede de sociabilidade que lhe permitiu desenvolver seus projetos. Por intermédio de amigos seus em Portugal, o seu livro chegou às mãos de Alexandre Herculano, cuja avaliação entusiasmada teve uma repercussão decisiva para que o poeta se tornasse conhecido e apreciado:

Receber uma declaração de independência literária das mãos de um dos mais aclamados homens de letras da antiga metrópole, num momento em que a nação se construía e se consolidava politicamente, certamente a revestia de um aspecto mais do que simbólico, pois era também político. Com a exaltação de Gonçalves Dias feita por Herculano, o Império Brasileiro não era mais independente apenas politicamente, ganhara o aval para ser autônomo 
em sua literatura e história, e não estariam justamente essas duas esferas entre as principais responsáveis pela construção da nação? (GONÇALVES; FARIA, 2013, p. 5)

No referido texto de Alexandre Herculano, publicado na Revista Universal Lisbonense em 1848 e depois, como prefácio da edição reunida dos Cantos de Dias, em 1857, o autor português afirma a decadência da literatura portuguesa e a ascensão da brasileira:

(...) porque a sociedade brasileira, vergôntea separada há tão pouco da carcomida árvore portuguesa, ainda necessariamente conserva uma parte do velho cepo. Possa o renovo dessa vergôntea, transplantada da Europa para entre os trópicos, prosperar e viver uma bem longa vida, e não decair tão cedo como nós decaímos! (HERCULANO In DIAS, 1998, p. 99)

Note-se como Herculano enxerga a literatura brasileira como uma continuação da portuguesa, como uma filha que carrega consigo a herança dos pais. No entanto, estimula a alienação dos valores portugueses quando afirma, mais à frente no mesmo artigo:

Quiséramos que as "Poesias Americanas" que são como o pórtico do edifício ocupassem nele maior espaço. Nos poetas transatlânticos há por via de regra demasiadas reminiscências da Europa. Esse Novo Mundo que deu tanta poesia a Saint-Pierre e a Chateaubriand é assaz rico para inspirar e nutrir os poetas que crescerem à sombra das suas selvas primitivas. (HERCULANO in DIAS, 1998, p. 100)

Gonçalves Dias atende o pedido e prossegue na sua poesia indianista. É interessante como todos os seus projetos literários passam sempre pela memória da terra deixada para trás. Em suas cartas a Teófilo Leal, fala num "romance histórico sobre o Maranhão" (cf. BANDEIRA, 1998, p. 27); numa chácara de um amigo maranhense, na Gávea, surge-lhe a ideia de Os Timbiras. Em junho de 1848 apareceram os Segundos Cantos, que alcançou da crítica e do público o mesmo favor que o primeiro. Tornou-se professor do Colégio Pedro II e membro ativo do Instituto Histórico, pelo qual foi incumbido, em 1949, no programa das teses distribuídas a vários sócios pelo imperador, de "comparar o estado dos indígenas da quinta parte do mundo com os do Brasil, considerados uns e outros na época da respectiva descoberta, e deduzir quais ofereciam maiores probabilidades à empresa da civilização", origem da memória Brasil e Oceania, lida no ano seguinte (Idem, Ibidem, p. 32).

Sobre este estudo, são de grande relevância as observações de KODAMA (2004, p. 67):

Brasil e Oceania foi escrita em duas partes, a primeira na qual o autor analisa os índios brasileiros, em que começa buscando determinar sua "origem" geográfica, ou o que chama de a "Judéia" dos índios brasileiros, que estaria em sua opinião no Amazonas (...). Na segunda parte da memória, o autor trataria dos povos da Oceania, juntando as informações de relatos de viagem de exploradores do continente austral.

Aqui conjugam-se as intenções de poeta e de etnógrafo/historiador, como o próprio Gonçalves Dias acreditava ser importante (cf. Idem, 2004). Na sua ânsia por construir um 
passado mítico para a nação brasileira, Dias está constantemente à procura de uma origem, e a comparação que faz com a "geografia simbólica" do povo judeu, é sintomática a este respeito. Vale destacar ainda o interesse nutrido pelos intelectuais do século XIX sobre o "Novíssimo Continente", visto como exótico, sempre com um olhar colonizador. Aliás, acerca deste olhar na memória do poeta, Kaori Kodama $(2004$, p. 8) salienta que

Gonçalves Dias trata de uma divisão dos índios brasileiros, recorrente na etnografia do século XIX: a que contrapunha tupis e tapuias. Não por simples coincidência (...), esta percepção reforçava a divisão dos grupos indígenas saídas [sic] dos relatos coloniais, que tendiam a contrapor os índios do litoral - os grupos tupis que em grande parte fizeram alianças com portugueses e sofreram aculturação no processo de colonização - e os índios do sertão. Entretanto, nem todos os etnógrafos que passaram pela América na primeira metade do século XIX confirmaram esta mesma divisão. Alcides d'Orbigny, por exemplo, colocava em um único grupo todos os índios da maior parte do Brasil, como brasilio-guaranys. Martius identificaria 8 ou mais grupos, ou "raças", de acordo com o que percebia como "dialetos" diferentes.

A este respeito, a autora acrescenta ainda:

O que mais chama a atenção nesta distinção de duas principais "nações" é a caracterização das tribos tupis, que coincide com sua visão romântica do índio, basicamente, a do "índio manso", assegurado pelo contato com a "civilização", o que lhe permitia também retirar os atributos morais desejáveis. A separação feita por Dias recai na antiga percepção colonial das diferenças das diversas tribos indígenas, e que se mantinha no século XIX, na divisão entre índios mansos e índios bravos. (KODAMA, 2004, p. 9)

Percebe-se aqui como o discurso científico da época e a proximidade com a identidade do colonizador tiveram influência sobre as representações gonçalvinas do indígena brasileiro. Apesar de aqui não se tratar propriamente de um de seus textos literários, observa-se uma mesma orientação (declarada pelo próprio autor) e uma fonte para identificar as características que ele desejava ressaltar no índio, equiparando-o às virtudes morais europeias/medievais. Os índios chamados "bravos", por exemplo, são aqueles que participaram na Confederação dos Tamoios (tema, aliás, abordado também por outro poeta romântico, Gonçalves de Magalhães), um movimento de resistência aos colonizadores.

Com base nestas experiências no Norte, o poeta lançou, em princípios de 51, os Últimos Cantos, ainda no Rio de Janeiro, onde está, segundo BANDEIRA (1998, p. 33) “o ápice da sua inspiração indianista, com os poemas 'I-Juca-Pirama', 'Marabá' e 'Leito de folhas verdes'." Repare-se aqui em como o projeto de construção da identidade nacional pelo indianismo se coaduna à memória e também ao aprendizado que teve no contato com o romantismo europeu, naquilo que em sua obra se aproxima dos modelos medievais de virtude e de guerreiro.

Nessa altura o poeta queria muito rever o Maranhão, pelo que pleiteou, no ano seguinte, uma licença sem vencimentos e uma passagem do Estado. Recebeu, em 
contrapartida, outra missão: a de estudar a instrução pública nas províncias do Norte e de recolher documentos históricos nos arquivos provinciais. Partiu, então, para o Norte em março de 1851.

Um motivo pessoal, além da vontade de estar próximo de familiares e amigos, prendia o poeta à terra natal: uma antiga paixão pela cunhada e prima de Alexandre Teófilo, chamada Ana Amélia. Durante a sua estada em casa do amigo na capital maranhense, anos antes, conheceu-a ainda menina e lhe fizera os versos "Leviana" e "Seus olhos" (cf. BANDEIRA, 1998, p. 34). O reencontro se reveste de importância para este estudo por envolver não só uma relação da biografia do poeta com os seus poemas, mas também uma barreira identitária sofrida pelo autor, que veio a repercutir em sua obra. Gonçalves Dias pede a mão da moça em casamento em carta à mãe e ao irmão da moça, também seu amigo. Nesta última, faz alusão à condição de filho ilegítimo e à condição de mestiço: "longe de ser nobre de sangue azul, nem ao menos sou filho legítimo" " (DIAS, 1998, p. 1074-1075), o que omite na carta à dona Lourença do Vale. Nesta, diz apenas que, em caso de resposta negativa, procuraria persuadirse que "algum motivo mais forte que a sua natural bondade terá obstado ao seu consentimento" (Idem, Ibidem). A resposta, de fato, foi negativa e breve - em apenas quatro linhas. A mãe da moça não revelou claramente o porquê de sua recusa, mas a maior parte dos biógrafos do poeta, entre eles Manuel Bandeira, aponta a origem mestiça de G. Dias como fator discriminatório à época, principalmente no Maranhão. Atribuem-se frequentemente a esta vivência os poemas "Se se morre de amor!", “Tu não queres ligar-te comigo" e "Ainda uma vez, adeus!", sendo este último escrito após um encontro casual de rua que teve com a amada na capital portuguesa, em maio de 55 (cf. BANDEIRA, 1998).

De volta ao Rio, resignado, casa-se com Olímpia Coriolano da Costa, filha de um membro do Instituto Histórico, e em 1851 é enviado pela Secretaria do Império para estudar os métodos de instrução pública em vários países da Europa e coligir nos arquivos estrangeiros documentos relativos à história do Brasil (op. cit., p. 39). Note-se aqui a continuidade do empenho imperial na construção da identidade brasileira, para a qual confiava no trabalho de Gonçalves Dias - e no seu olhar compatível com o do colonizador.

Os livros necessários à Comissão Científica foram adquiridos por intermédio de Brockhaus, editor alemão por quem tanto se entusiasmou o poeta, que o propôs para livreiro do Instituto Histórico e do imperador. Foi em sua editora que imprimiu os Cantos, em 57 - na

\footnotetext{
${ }^{3}$ Dias dizia-se "ilegítimo" pois sua mãe, Vicência Mendes Ferreira, era separada e vivera "amasiada" com seu pai, João Manuel Gonçalves Dias (cf. BANDEIRA, 1998, p. 13).
} 
qual, como já atrás se referiu, Dias incluiu o elogio de Herculano como prefácio -, recebendo, em seguida, críticas positivas e traduções de poemas seus - "Seus olhos", "Canção do exílio" e "O canto do guerreiro" para o alemão. Por incentivo de alguns filósofos alemães, Dias publica também o seu dicionário tupi. Em outubro do mesmo ano, vem à luz ainda os quatro cantos d'Os Timbiras, escritos havia dez anos.

Devido à grande saída d'Os Cantos no Brasil, na Alemanha, na França, na Espanha e em Portugal, o impressor Brockhaus custeou a segunda edição. Espalharam-se, assim, pelo Brasil e pela Europa, representações da cultura brasileira através da consciência contrapontística do exílio e da incrustação de valores europeus ao elemento nativo brasileiro. No entanto, pode-se ler em poemas como "O canto do guerreiro" uma tentativa de afirmar a não-passividade dos nativos à colonização, pelo menos no início, o que demonstraria a força da sua identidade:

I

\begin{abstract}
Aqui na floresta
Dos ventos batida,

Façanhas de bravos

Não geram escravos,

Que estimem a vida,

Sem guerra e lidar.

- Ouvi-me, Guerreiros.

- Ouvi meu Cantar.
\end{abstract}

\section{(...)}

VI

Se as matas estrujo

Co os sons do Boré, Mil arcos se encurvam,

Mil setas lá voam,

Mil gritos reboam,

Mil homens de pé

Eis surgem, respondem

Aos sons do Boré!

- Quem é mais valente,

- Mais forte quem é?

(...)

(DIAS, 1998, p. 106-107)

[Em nota:] Boré, instrumento músico de guerra: dá apenas algumas notas, porém mais ásperas, e talvez mais fortes que as da trompa. (DIAS, 1998, p. 559)

No poema, Dias inclui palavras indígenas e notas para que o leitor as entenda, revelando ao mesmo tempo uma defesa da identidade do colonizado e um anseio de ser legível ao público europeu (e mesmo ao brasileiro, uma vez que tais termos não pertenciam nem pertencem, em sua maioria, ao vocabulário da linguagem corrente dos leitores). A bravura do índio é um atributo ambíguo, pois a resistência que impôs ao colonizador é valorizada tanto por este, enquanto dignidade semelhante à dos cavaleiros medievais, quanto pelo próprio índio, que via a morte de guerra com o orgulho de um mártir. Nas representações brasileiras posteriores, o índio aparecerá muito mais como "manso" do que como "bravo", e é 
a sua lógica de mundo que se imporá à leitura, ao invés do movimento contrário - como no caso de Macunaíma, de Mário de Andrade.

Há ainda outro aspecto de interpretação um tanto dúbia na poesia de Gonçalves Dias no que toca à identidade brasileira: é o poema "Marabá". Segundo nota do autor (DIAS, 1998, p. 563), teria ele encontrado o seguinte relato numa crônica de viagem: “"Tinha certa velha enterrado vivo um menino, filho de sua nora, no mesmo ponto em que o parira, por ser filho a que chamam marabá, que quer dizer de mistura (aborrecível entre esta gente).'”. No poema (DIAS, 1998, p. 392-393), quem fala é uma índia marabá, branca, loira, dos olhos azuis, que é sucessivamente rejeitada pelos índios de sua tribo pelas suas características físicas. Alguns críticos (cf. RONCARI, 2002; FERNANDES, 1989) veem aqui um contraponto entre o ideal de beleza europeu e o indígena, sob a ótica deste; enquanto outros o interpretam como um lamento diante da condição mestiça e da "pureza da raça" perdida. É oportuno lembrar, contudo, que a mestiçagem como ideologia só tomou corpo no ambiente literário brasileiro a partir de finais do século XIX, e, mesmo assim, numa perspectiva determinista na qual o mestiço encerra os defeitos e as taras transmitidos pela herança biológica (cf. ORTIZ, 1994).

O certo é que Gonçalves Dias não se furtou a denunciar a ambição desmedida do colonizador, nem mesmo pelas relações que estabelecia com Portugal. Em "I-Juca-Pirama", cujo título quer dizer, em português, algo como "o que há de ser morto, e é digno de ser morto" (DIAS, 1998, p. 561), narra-se a história de um jovem guerreiro da tribo Tupi que, após ter sido capturado pelos índios Timbiras, estava prestes a ser devorado pelos índios. No entanto, demonstra fraqueza ao pensar em abandonar seu pai, pelo que a tribo o solta. O pai do índio, desgostoso com a covardia do filho, leva-o de volta à tribo e se orgulha da bravura com que luta até a morte:

No meio das tabas de amenos verdores, Cercados de troncos - cobertos de flores, Alteiam-se os tetos d'altiva nação;

São muitos seus filhos, nos ânimos fortes,

Temíveis na guerra, que em densas coortes

Assombram das matas a imensa extensão.

(...)

- Basta! Clama o chefe dos Timbiras,

- Basta, guerreiro ilustre! Assaz lutaste,

E para o sacrifício é mister forças. -

O guerreiro parou, caiu nos braços

Do velho pai, que o cinge contra o peito,

Com lágrimas de júbilo bradando:

"Este, sim, que é o meu filho muito amado!” (...) (DIAS, 1998, p. 379 e 391). 
Aqui, o autor desconstrói a ideia da antropofagia como mera alimentação e a retrata como um ritual em que só os seres considerados virtuosos poderiam morrer. Desta forma, contrasta ideias do colonizador e do colonizado, utilizando-se, porém, de um elemento comum às duas culturas - a noção do sacrifício, do bode expiatório.

As representações do exílio e do nacionalismo, entrelaçadas dialeticamente, demandam em Gonçalves Dias um estudo aprofundado de sua vida e de sua obra (também tão relacionadas) para o qual tentou-se, no presente ensaio, deixar um pequeno contributo, sem, no entanto, entrar em análises exaustivas. Buscou-se mostrar como o exílio voluntário do poeta em Portugal teve papel preponderante em sua visão da pátria, por meio do contraponto entre a memória do lugar natal, idealizado pela distância, e do espaço onde se encontrava, menosprezado, de certa forma, pela circunstância de o separar daquilo que ele considerava seu. Demonstrou-se como o mesmo processo ocorre quando de volta ao Brasil, passados alguns anos, manifesto numa representação positiva do ambiente português e negativa - em alguns textos - da terra natal; ponto em que se refletiu sob a perspectiva experiencial.

A leitura da biografia e dos poemas e cartas do poeta sugeriu também que, em sua ida ao Rio de Janeiro, o poeta viveu uma segunda experiência de migração/exílio, pois ali se debatia constantemente entre o provincianismo e o cosmopolitismo, além de se encontrar quase tão distante geograficamente de sua terra natal quanto estava quando viveu na Europa. Acompanhando o seu percurso de viagens ao Norte e ao continente europeu, observaram-se as relações literárias estabelecidas e as suas consequências na construção de um ideário acerca do "ser brasileiro", tanto no Brasil quanto no exterior. Nas representações do nacional em Gonçalves Dias, construídas a partir do duplo olhar do exilado, se materializam conflitos de identidade, cruzando-se olhares do colonizado e do colonizador num amálgama de que era testemunha viva a própria pessoa do poeta.

\section{Referências}

BANDEIRA, Manuel. A Vida e a Obra do Poeta. In: DIAS, Gonçalves. Poesia e Prosa Completas. 1. ed. Rio de Janeiro: Nova Aguilar, 1998. (Biblioteca Luso-brasileira)

CANDIDO, Antonio. Formação da literatura brasileira: (momentos decisivos). 6. ed. v. 1 e 2. Belo Horizonte: Itatiaia, 2000. (Coleção reconquista do Brasil)

Literatura e sociedade. 11. ed., Rio de Janeiro, Ouro sobre Azul, 2010.

CINTRÃO, Sylvia Helena. A ideologia nas Canções de Exílio: ufanismo e crítica. 1988. 121 f. (Dissertação) (Mestre) - UnB, Brasília, 1988. 
COUTINHO, Milson. Caxias das Aldeias Altas: subsídios para sua história. 2. ed. Caxias: Prefeitura de Caxias, 2005.

FERNANDES, Florestan. A organização social dos Tupinambá. São Paulo: Hucitec/UNB, 1989.

GONÇALVES, Márcia de Almeida; FARIA, Andréa Camila de. Entre projetos literários e políticos: a literatura de Gonçalves Dias e a identidade brasileira, Anais do III Simpósio de História do Maranhão Oitocentista: impressos do Brasil do século XIX. São Luís: UEMA, 2013. Disponível em <www.outrostempos.uema.br/oitocentista/cd/ARQ/38.pdf>. Acesso em 26 ago./2014.

GRIZOSTE, Weberson Fernandes. Gonçalves Dias e a Procura da Identidade Nacional Brasileira. Brasiliana - Journal for Brazilian studies. v. 2, n. 2, p. 371-400, nov. 2013.

HALL, Stuart. A identidade cultural na pós-modernidade. Tradução de Tomaz Tadeu da Silva e Guacira Lopes Louro. 11. ed., Rio de Janeiro: DP\&A, 2006.

KODAMA, Kaori. O tupi e o sabiá: Gonçalves Dias e a etnografia do IHGB em Brasil e Oceania, Fênix - Revista de História e Estudos Culturais, v. 4, ano 4, n. 3, jul./ago./set. 2007, p. 1-14. Disponível em: < http://www.revistafenix.pro.br/vol12Kaori.php>. Acesso em 28 ago. 2014.

LIMA, Henrique de Campos Ferreira. Gonçalves Dias em Portugal. Coimbra: Coimbra Editora, 1942.

MARQUES, César Augusto. Dicionário Histórico e Geográfico do Maranhão. 3. ed., Rio de Janeiro: Cia. Editora Fon-Fon e Seleta, 1970.

MESQUITA, Maria Auxiliadora Gonçalves de. O exílio e suas canções na literatura brasileira: um recorte analítico. 2001. 88f. (Dissertação) (Mestre) - UFRJ, Rio de Janeiro, 2001.

NANCY, Jean-Luc. La existencia exiliada. Tradução de Juan Gabriel López Guix Archipiélago. Cuadernos de crítica de la cultura. Barcelona, n. 26-27, p. 34-39, 1996.

ORTIZ, Renato. Cultura brasileira e identidade nacional. 5. ed., São Paulo: Brasiliense, 1994.

RICARDO, Cassiano. O indianismo de Gonçalves Dias. São Paulo: Conselho Estadual de Cultura, 1964.

RONCARI, Luiz. Literatura brasileira: dos primeiros cronistas aos últimos românticos. 2. ed. São Paulo: Editora da Universidade de São Paulo, 2002.

SAID, Edward. Reflexões sobre o exílio e outros ensaios. Tradução de Pedro Maia Soares. São Paulo: Companhia das Letras, 2003.

TUAN, Yi-Fu. Espaço e Lugar: a perspectiva da experiência. Tradução de Lívia de Oliveira. São Paulo/Rio de Janeiro: DIFEL, 1983. 